\title{
Kajian Sirkulasi Ruang Koleksi pada Perpustakaan Universitas Lampung (Unila)
}

\author{
Ai Siti Munawaroh ${ }^{1}$, Neneng Widiana Fitri ${ }^{1}$ \\ ${ }^{1}$ Program Studi Arsitektur, Fakultas Teknik, Universitas Bandar Lampung \\ *Penulis Korespondesi: aisiti.arch@ubl.ac.id
}

\begin{abstract}
Abstrak:
Ruang koleksi merupakan salah satu ruang penunjang perpustakaan yang paling penting. Kuantitas dan kualitas koleksi mempengaruhi minat pengguna perpustakaan untuk membaca. Di sisi lain, ruang koleksi terdiri dari perabot, buku, manusia dan aktivitas manusia yang ada di dalamnya.Penelitian ini bertujuan untuk mengetahui sirkulasi ruang koleksi perpustakaan Unila dan membandingkannya dengan standar. Metode penelitian menggunakan metode kualitatif deskriptif. Data diperoleh melalui studi lapangan. Data denah dan dimensi perabot didapatkan dengan menggambar ulang berdasarkan ukuran lapangan. Data dianalisis dengan cara membandingkan hasil pengukuran dengan standar. Hasil penelitian didapat: 1) Sirkulasi ruang gerak pada ruang koleksi lantai 1 perpustakaan Universitas Lampung memiliki dimensi antar rak koleksi yang tidak sesuai dengan standar, dan dimensi antar rak koleksi ke meja baca tanpa adanya kursi juga tidak memenuhi standar; 2) Sirkulasi ruang gerak pada ruang koleksi lantai 2 area baca perpustakaan Universitas Lampung pada dimensi antar rak koleksi dan jarak untuk jalur sirkulasi pada zona (1) - (3) memiliki jarak yang tidak sesuai dengan standar. Sementara sirkulasi untuk dimensi antar rak koleksi ke meja baca dengan kursi, pada zona (1) jarak sudah memenuhi standar dan zona (3) jarak tersebut masih kurang dari standar; 3) Sirkulasi ruang gerak pada ruang koleksi lantai 3 memiliki dimensi antar rak koleksi yang tidak memenuhi standar untuk ruang gerak pengguna dalam melakukan aktivitas dan jarak rak koleksi dengan meja baca tanpa kursi juga tidak memenuhi standar, sedangkan dimensi antara rak koleksi dan meja baca yang memiliki kursi pada area 1 jarak sudah memenuhi standar dan area 3 jarak tersebut sudah memenuhi.
\end{abstract}

Kata Kunci: sikrulasi; ruang koleksi; perpustakaan; lampung; unila

\section{Latar Belakang}

Ruang koleksi adalah salah satu ruang penunjang perpustakaan yang paling penting. Minat pengguna perpustakaan biasanya dipengaruhi oleh jumlah dan kualitas koleksi yang ada. Di satu sisi ruang koleksi juga terdiri dari perabot, buku, manusia dan aktivitas manusia yang ada di dalamnya.Penelitian mengenai pengaruh ruang terhadap minat pengunjung di salah satu perpusakaan di Bandung menunjukkan bahwa ada hubungan antara keduanya. Perabot dari perpustakaan dapat menumbuhkan minat pengunjung untuk datang ke perpustakaan(Noviani et al., 2014),

Selain perabot, aktivitas manusia yang ada di dalamnya membutuhkan ruang yang disebut dengan ruang sirkulasi. Beberapa penelitian mengenai hubungan sirkulasi dengan kenyamanan telah dilakukan diantaranya penelitian tentang ruang sirkulasi dan pengaruhnya terhadap kenyamanan di sebuah SMK Negeri di Pacitan dan menemukan bahwa kenyamanan pengguna terhadap dimensi ruang sirkulasi berkurang karena terlalu ruang terlalu sempit dan tidak memenuhi standar (Listiani, 2007). Penelitian sejenis dilakukan diantaranya di ruang tunggu sebuah bank(Andadari, Indrosaptono, \& Sari, 2019), di perpustakaan universitas swasta (Sainttyauw, 2011), di Badan Perpustakaan dan Arsip Daerah (BPAD) (Mansyur, 2017), di Perpustakaan BPS Provinsi (Fadhlun \& Rahman, 2020), di pusat perbelanjaan(Syoufa \& Hapsari, 2014)(Pynkyawati, G, Hendarsyah, \& Amhar, 2012)(Pynkyawati, Aripin, Iliyasa, \& Ningsih, 2014)(Susanto, 2017), di mesjid (Safriana, 2017), di museum(Limantara et al., 2017), di rumah sakit (Suwantoro \& Munawaroh, 2017), di ruang IGD rumah sakit islam (Handoko, 2010), dan di stasiun kereta api (Syafiq et al., 2015).

Ruang untuk sirkulasi pada perpustakaan ada standarnya.Jarak antar lorong rak minimaladalah $130 \mathrm{~cm}$, sedangkan untuk ruangsirkulasi pengguna yaitu $150 \mathrm{~cm}$, dan jarak yang standar pada perpustakaan umum adalah $230 \mathrm{~cm}$. Jarak minimal antar rak buku ke meja baca adalah $90 \mathrm{~cm}$ tanpa kursi, sedangkan jarak minimum antar rak buku ke meja baca dengan kursi adalah $120 \mathrm{~cm}$ (Neufert, 2002).

Beberapa penelitian tentang sirkulasi pada ruang baca perpustakaan telah dilakukan diantaranya penelitiandi universitas swasta di Bandung dan menemukan bahwa jarak sirkulasi belum sesuai standar (Salsabilla et al., 2019). 
Penelitian lain menemukan bahwa sirkulasi di ruang baca perpustakaan Universitas Lampung (universitas negeri) belum mendekati jarak sesuai standar. Jarak antara meja baca di ruang baca kurang dari standar, sedangkan jarak sirkulasi antara rak buku dan meja baca melebihi standar yang dianjurkan (Widiana \& Munawaroh, 2020). Beberapa penelitian terdahulu baru meneliti ruang baca. Sedangkan ruang koleksi yang merupakan bagian dari perpustakaan belum ada yang meneliti. Padahal ruang koleksi merupakan tempat yang penting dalam menunjang aktvitas menyimpan dan mencari koleksi, tetapi biasanya menjadi tempat yang kurang diperhatikan, Ruang koleksi juga terkadang tidak diperhatikan penataanya, baik dimensi perabot maupun jarak antar perabot. Padahal ada standar yang harus dipenuhi. Penelitian ini bertujuan untuk mengkaji ruang koleksi perpustakaan Unila berdasarkan standar.

\section{Metode}

Metode kualitatif deskriptif digunakan dalam penelitian ini. Penelitian deskriptif merupakan metode penelitian yang cocok untuk penelitian ini karena dengan metode ini dapat ditemukannya pengetahuan mengenai objek (Syah, 2010).Selain itu, dengan metode ini objek dapat dijelaskan dan dideskripsikan secara luas baik dengan menggunkan angka maupun kata (Setyosari, 2010)(Sukmadinata, 2006).

\subsection{Metode Pengumpulan Data}

Observasi lapangan dan pengukuran adalah teknik pengumpulan data yang dilakukan. Data berupa denah dan dokumentasi situasi di dalam Perpustakaan. Adapun teknik pengumpulan data penelitian sebagai berikut:

1. Data mengenai denah ruang baca perpustakaan di Universitas Lampung dilakukan dengan menggambar ulang menggunakan software.

2. Data pengukuran jarak antar perabot dan luas ruangan didalam perpustakaan diukur dengan menggunakan meteran. 2.2 Metode Analisis Data

Hasil pengukuran ruang sirkulasi ruang koleksi Perpustakaan Universitas Lampung dibandingkan dengan standar sirkulasi.

\section{Hasil dan Pembahasan}

Perpustakaan Universitas Lampung (Unila) berlokasi di Jl Soemantri Brojonegoro Gedung Meneng, Gedong Meneng, Rajabasa, Kota Bandar Lampung, Lampung.

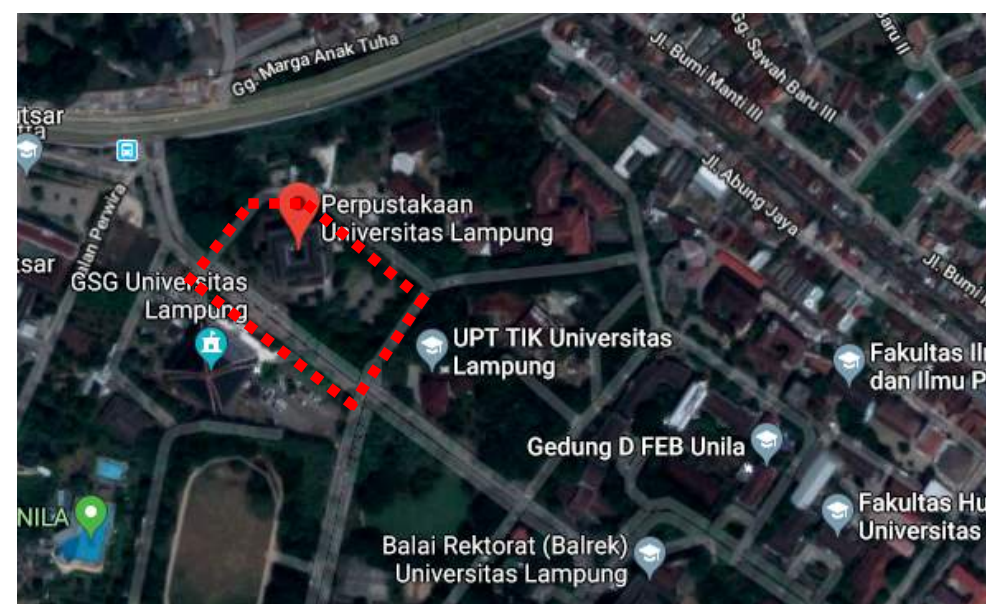

Gambar 1. Lokasi Perpustakaan Unila

(Sumber: Googlemaps, 2019)

Perpustakaan Universitas Lampung memiliki beberapa ruang diantaranya ruang baca, ruang baca lesehan, ruang koleksi buku, dan ruang layanan sirkulasi atau administrasi.Ruang koleksi buku yang terdapat pada area baca perpustakaan Unila. Dari lantai 1 sampai lantai 3 memiliki pola penataan ruang yang berbeda.

\subsection{Ruang Koleksi Buku Lantai 1}

Pada ruang koleksi buku lantai 1 perpustakaan Universitas Lampung terdapat 1 zona area koleksi, seperti terlihat pada gambar berikut: 


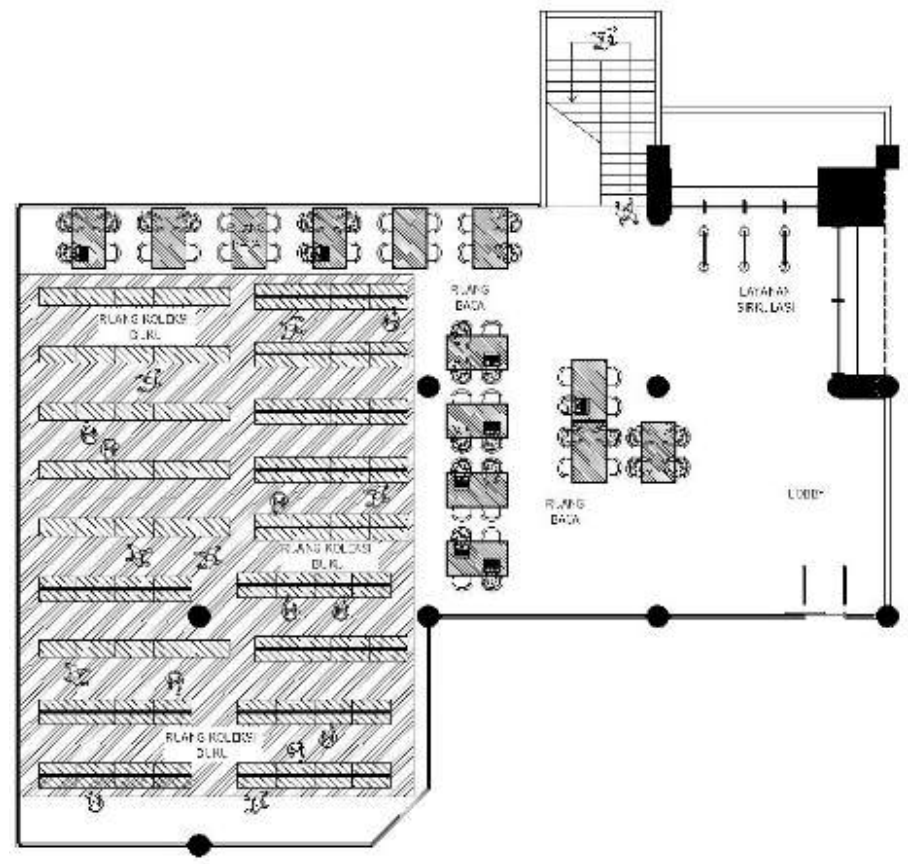

Gambar 2. Denah Perpustakaan lantai 1

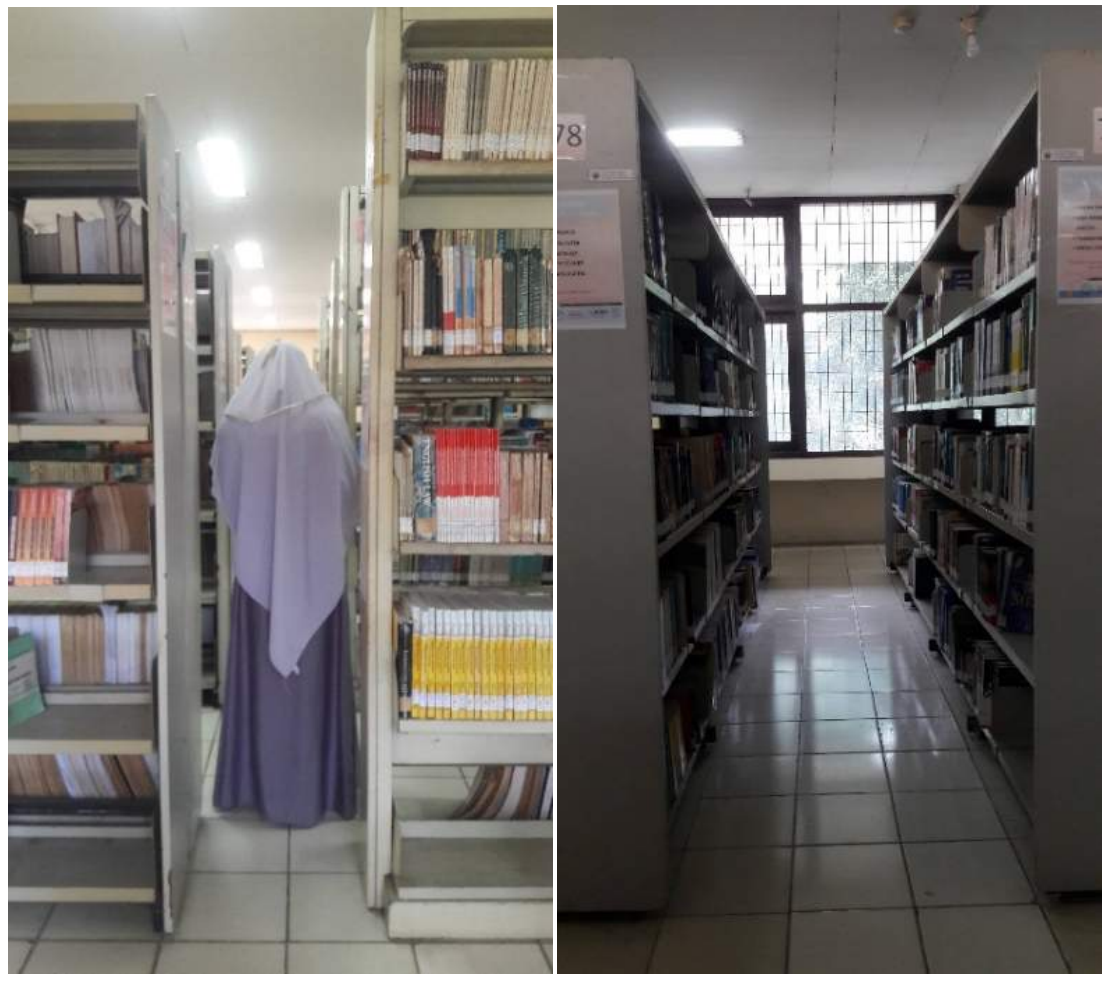

Gambar 3.Suasana ruang koleksi lantai 1 


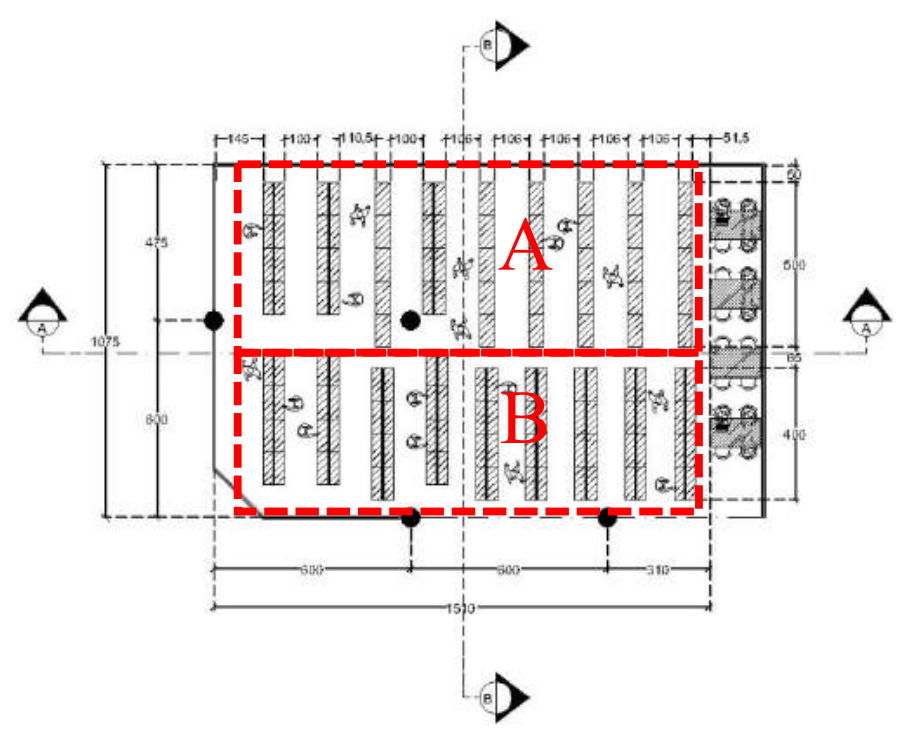

Keterangan:

A. Baris 1

B. Baris 2

Gambar 4. Zona ruang koleksi lantai 1

Pada ruang koleksi lantai 1 terdapat 18unit rak buku yang dibagi dalam 2 baris dan setiap barisnya memiliki 9 shaf. Pada ruang koleksi lantai 1 terdapat rak koleksi 1 dan 2 yang disusun secara terpisah. Seperti terlihat pada gambar berikut:

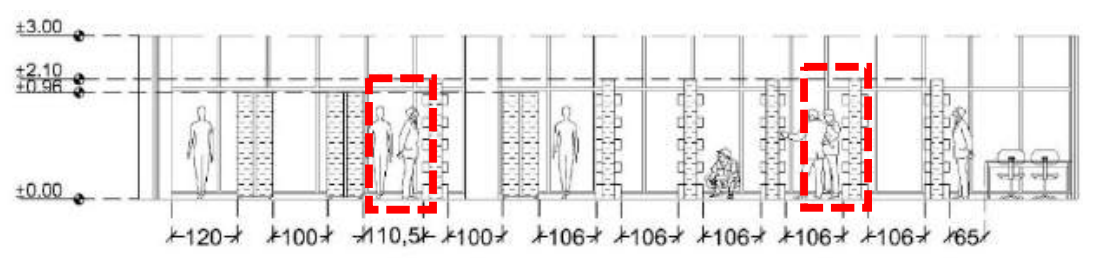

Gambar 5.Potongan A-A ruang koleksi lantai 1 (1)rak koleksi 1 (2)rak koleksi 2

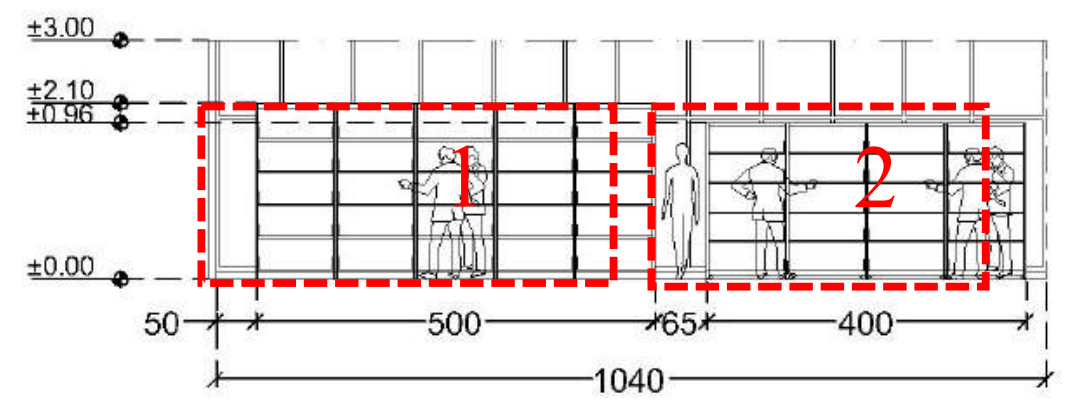

Gambar 6. Potongan B-B ruang koleksi lantai 1 (1) rak koleksi 1 (2) rak koleksi 2

Pada ruang koleksi aktivitas yang sering dilakukan pengguna adalah duduk jongkok, membaca dan berdiri. Dan sirkulasi ruang gerak pada ruang koleksi lantai 1 kurang memenuhi kebutuhan pengguna dalam melakukan aktivitas tersebut karena terlalu sempitnya jarak antar perabot. Berikut perbandingan analisis standar ukuran jarak antar perabot pada ruang koleksi lantai 1. 
Tabel 1. Perbandingan ukuran jarak perabot pada ruang koleksi lantai 1 terhadap standar ukuran jarak
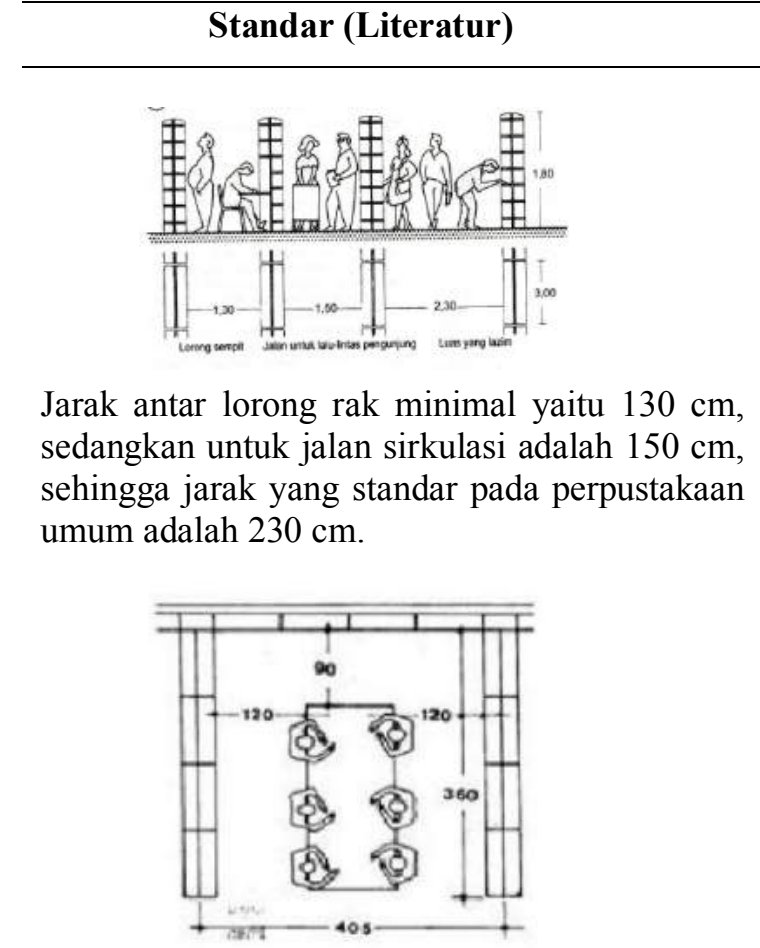

Jarak minimum antara rak buku dan meja baca yaitu $90 \mathrm{~cm}$ tanpa kursi, sedangkan jarak minimum antara rak buku dan meja baca dengan kursi yaitu $120 \mathrm{~cm}$.

Tabel diatas menunjukan sirkulasi ruang gerak pada ruang koleksi lantai 1 perpustakaan Universitas Lampung memiliki dimensi antar rak koleksi yang tidak sesuai dengan standar. Menurut Neufert (2002) ukuran jarak yang dianjurkan yaitu $130 \mathrm{~cm}-230 \mathrm{~cm}$. Sedangkan dimensi antar rak koleksi ke meja baca tanpa adanya kursi juga tidak memenuhi standar. Menurut Neufert (2002) ukuran jarak yang dianjurkan yaitu $90 \mathrm{~cm}$ untuk jarak rak koleksi ke meja baca tanpa adanya kursi.

\subsection{Ruang Koleksi Lantai 2}

Ruang koleksi lantai 2 memiliki luasan area paling besar dari lantai 1 dan 3, seperti terlihat pada gambar berikut:

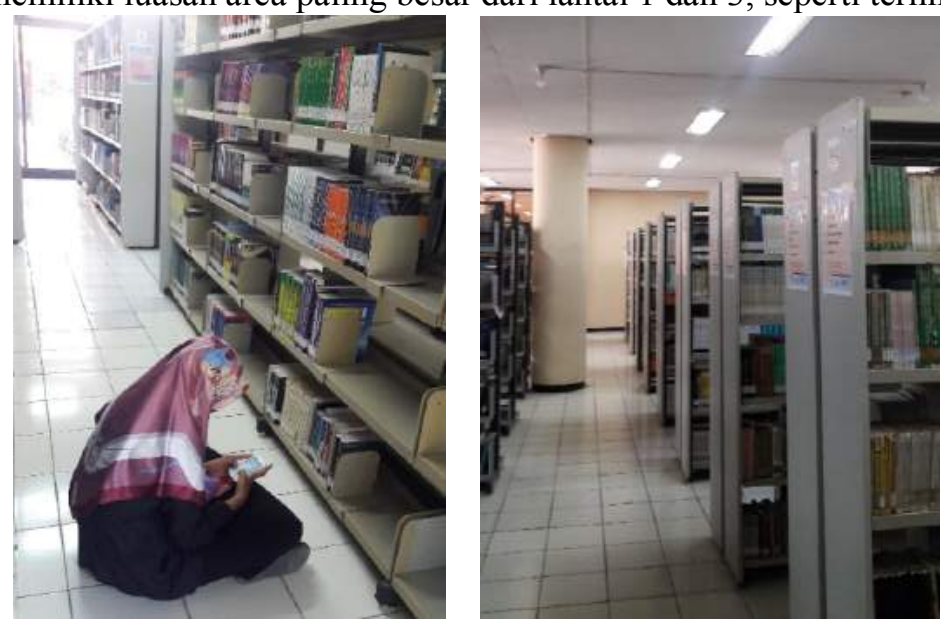

Gambar 7. Suasana ruang koleksi lantai 2 


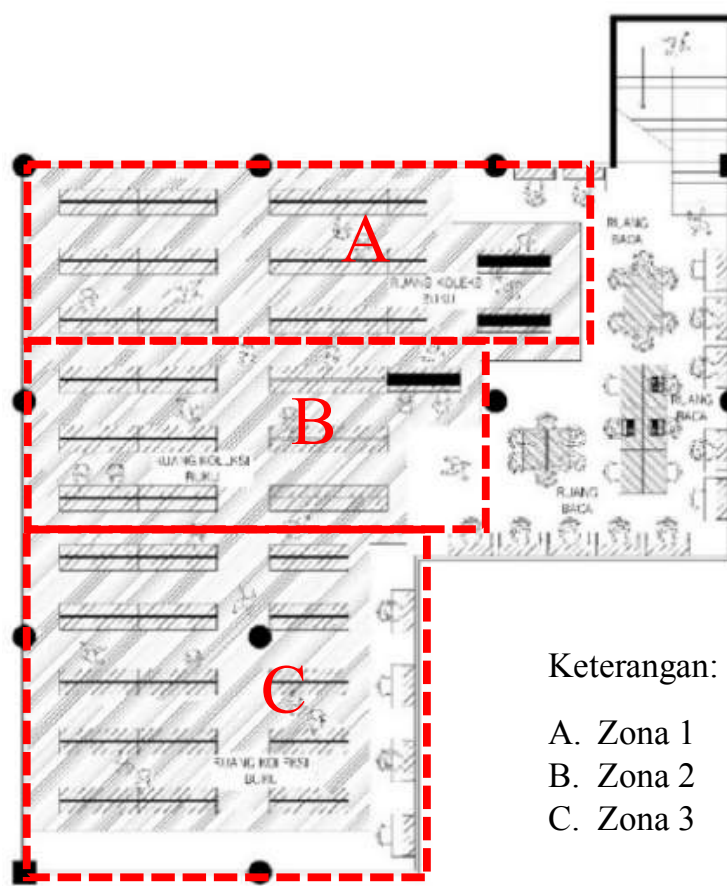

Gambar 8. Zona ruang koleksi lantai 2

Ruang koleksi lantai 2 terdapat rak koleksi 2,3,4 dan 5 dengan total 25unit rak koleksi. Ruang koleksi lantai 2 dibagi ke dalam 3 zona area seperti terlihat pada gambar diatas, dijelaskan sebagai berikut:

\subsubsection{Zona 1}

Zona 1 terdapat beberapa perabot yaitu 8unit rak koleksi terdiri dari 2unit rak koleksi 5 dan 6 unit rak koleksi 2, dan juga terdapat meja baca personal. Jarak antar perabot pada zona 1 seperti terlihat pada gambar berikut:

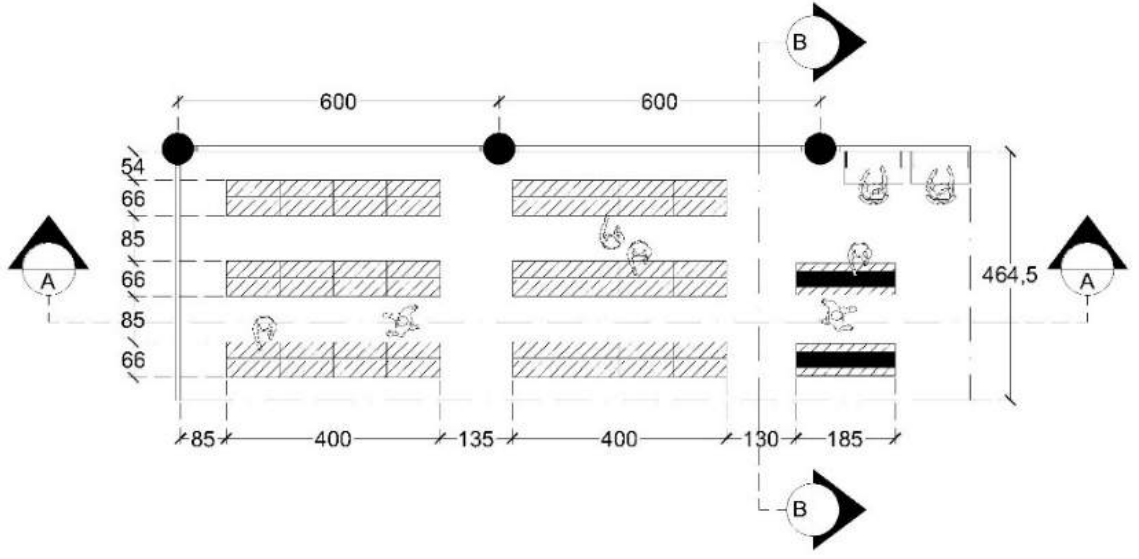

Gambar 9. Denah ruang koleksi lantai 2 zona 1

Dimensi antar rak koleksi yaitu $85 \mathrm{~cm}-91 \mathrm{~cm}$, sementara dimensi antar rak koleksi untuk jalan sirkulasi pengguna yaitu $130 \mathrm{~cm}-135 \mathrm{~cm}$, dimensi antar rak koleksi dengan dinding yaitu $85 \mathrm{~cm}$ dan jarak antara rak koleksi dan meja baca dengan kursi yaitu $148 \mathrm{~cm}$. 


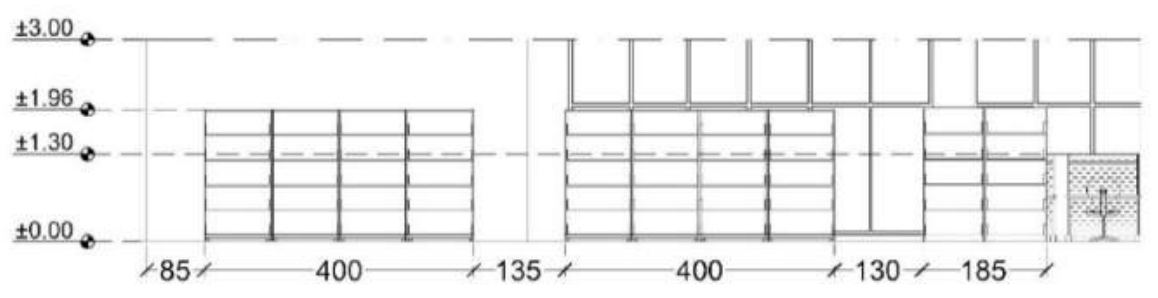

Gambar 10.Potongan A-A ruang koleksi lantai 2 zona 1

(Sumber: Data Pribadi, 2018)

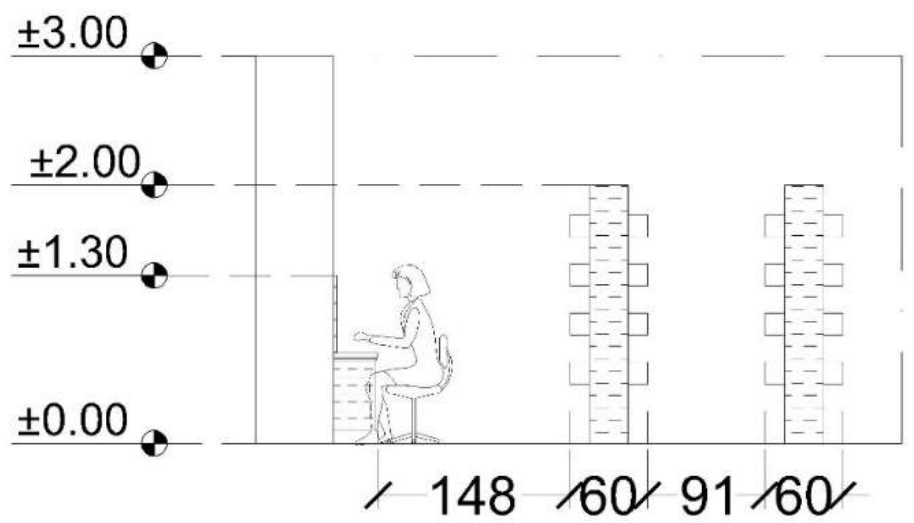

Gambar 11. Potongan B-B ruang koleksi lantai 2 zona 1

\subsubsection{Zona 2}

Zona 2 terdapat 3unit rak koleksi 2, 3 unit rak koleksi 3 dan 1 unit rak koleksi 5, yang disusun secara terpisah. Dimensi antar rak koleksi pada zona 2 seperti terlihat pada gambar berikut:

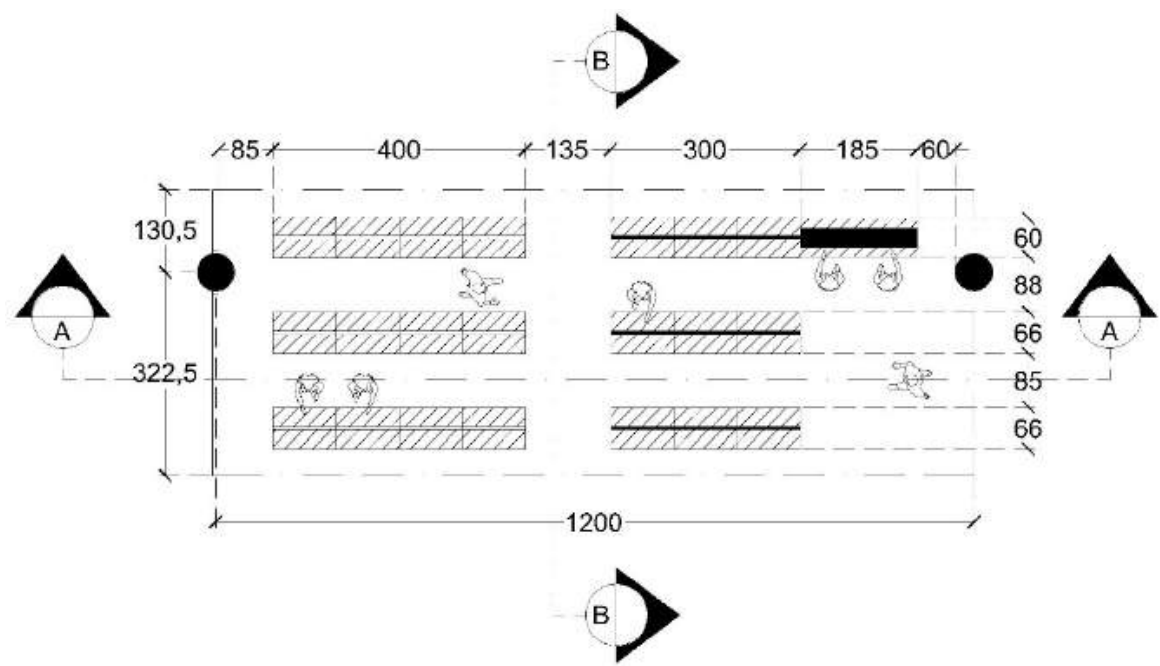

Gambar 12. Denah ruang koleksi lantai 2 zona 2

Dimensi antar rak koleksi untuk sirkulasi pengguna pada zona 2 yaitu $135 \mathrm{~cm}$, dimensi antar rak koleksi dengan dinding yaitu $85 \mathrm{~cm}$, dan dimensi antar rak koleksi yaitu $85 \mathrm{~cm}$. 


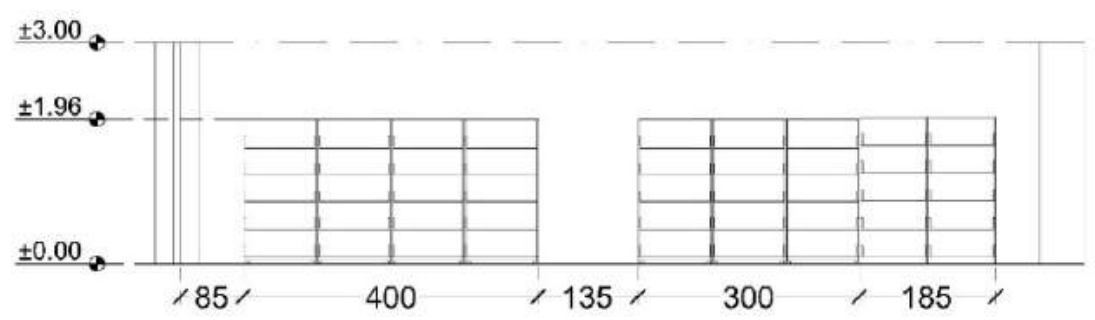

Gambar 13.Potongan A-A ruang koleksi lantai 2 zona 2

(Sumber: Data Pribadi, 2018)

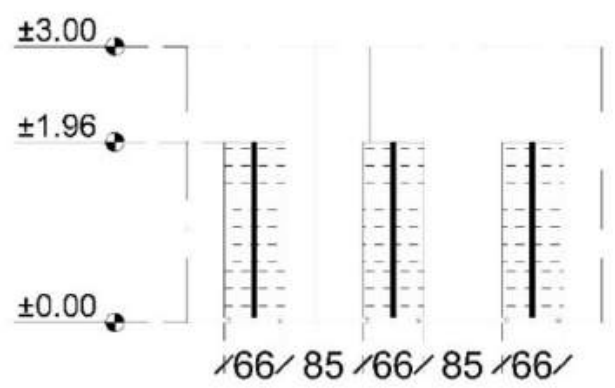

Gambar 14. Potongan B-B ruang koleksi lantai 2 zona 2

\subsubsection{Zona 3}

Zona 3 terdapat beberapat perabot didalamnya seperti 5 unit rak koleksi 2, 5 unit rak koleksi 4 dan 4 unit meja baca personal. Jarak antar perabot pada zona 3 seperti terlihat pada gambar berikut:

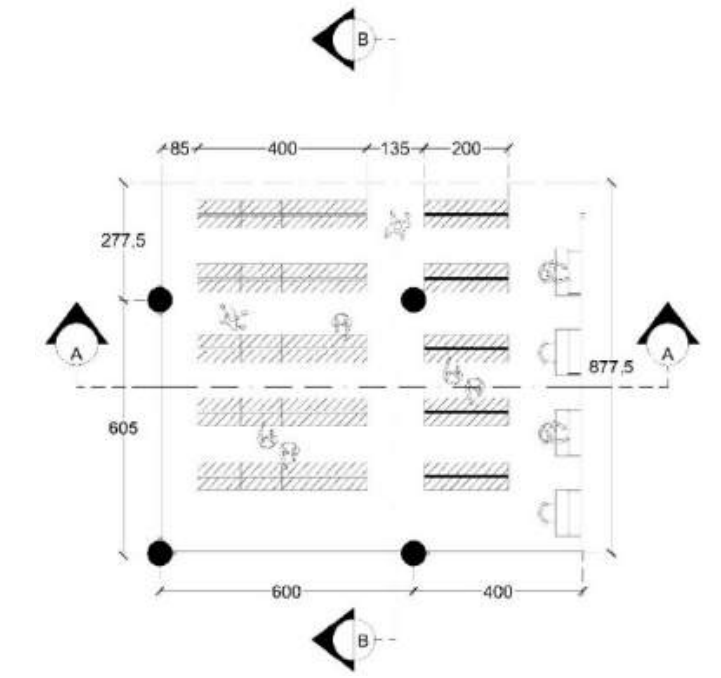

Gambar 15. Denah ruang koleksi lantai 2 zona 3

Jarak antar perabot pada zona 3 yaitu jarak antara rak koleksi dan meja baca dengan kursi $110 \mathrm{~cm}$, jarak antar koleksi $85 \mathrm{~cm}$, dimensi antar rak koleksi untuk jalan sirkulasi $135 \mathrm{~cm}$, dan dimensi antar rak koleksi dengan dinding $85 \mathrm{~cm}$. 


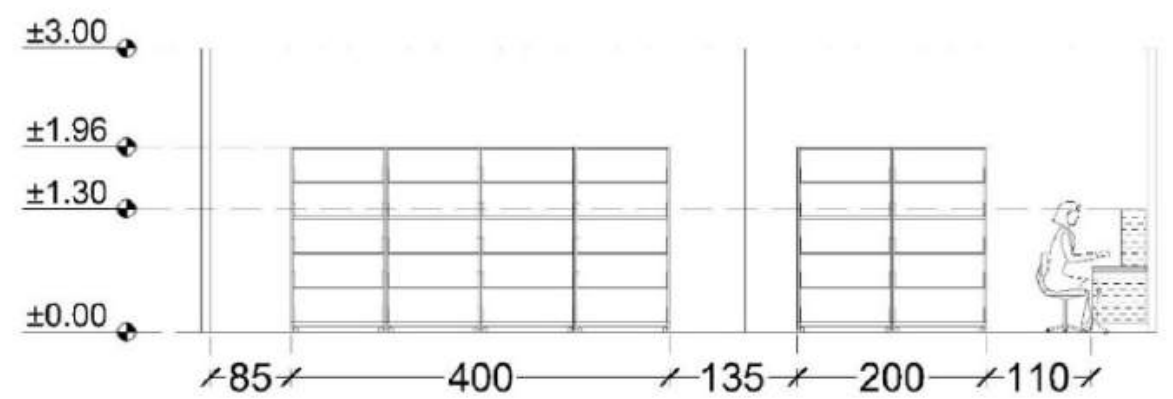

Gambar 16. Potongan A-A ruang koleksi lantai 2 zona 3

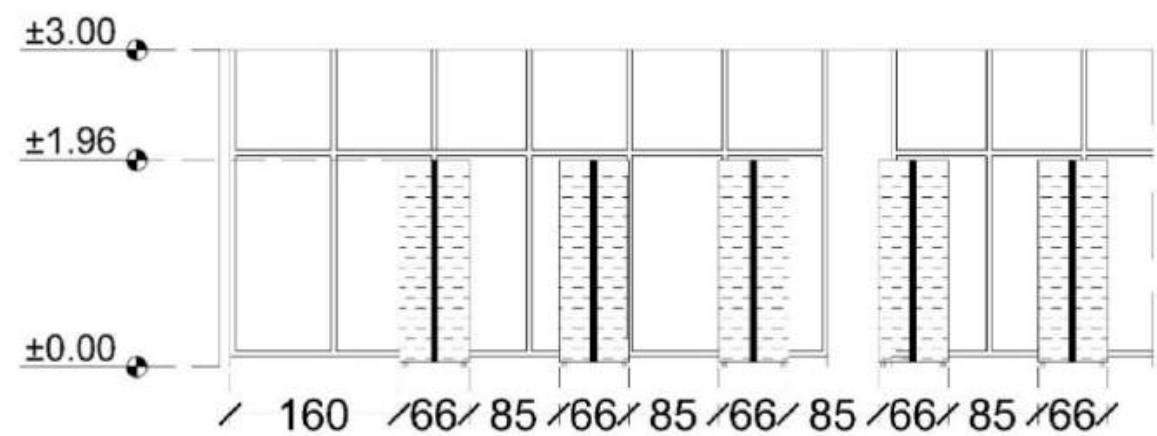

Gambar 17. Potongan B-B ruang koleksi lantai 2 zona 3

Ruang koleksi lantai 2 perpustakaan Universitas lampung memiliki sirkulasi ruang gerak yang kurang baik, seperti dijelaskan sebelumnya jarak antar perabot pada ruang koleksi yang terlalu sempit mengakibatkan pengguna tidak efektif dalam melakukan aktivitasnya. Berikut perbandingan analisis standar ukuran jarak antar perabot pada ruang koleksi lantai 2.

Tabel 2.Perbandingan ukuran jarak perabot pada ruang koleksi lantai 2 terhadap standar ukuran jarak

\section{Standar (Literatur)}

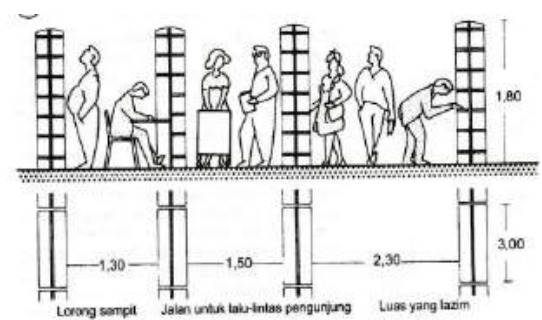

Jarak antar lorong rak minimal adalah $130 \mathrm{~cm}$, sedangkan untuk ruangsirkulasi pengguna adalah $150 \mathrm{~cm}$, sehingga jarak yang standar pada perpustakaan umum yaitu $230 \mathrm{~cm}$.

\section{Ruang Koleksi Lantai 2}

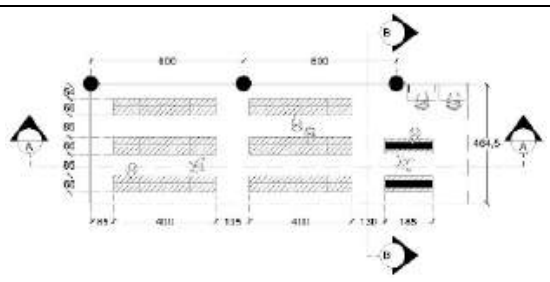

Pada zona 1 dimensi antar rak koleksi yaitu $91 \mathrm{~cm}$, jarak antara rak koleksi dan meja baca dengan kursi yaitu $148 \mathrm{~cm}$ dan untuk jarak jalan sirkulasi $130 \mathrm{~cm}-135 \mathrm{~cm}$.

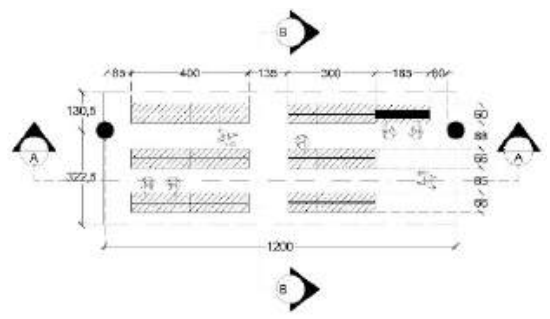

Pada zona 2 memiliki jarak untuk jalan sirkulasi yaitu $135 \mathrm{~cm}$, dimensi antar rak koleksi $85 \mathrm{~cm}$ dan dimensi antar rak koleksi dengan dinding $85 \mathrm{~cm}$. 


\section{Standar (Literatur)}

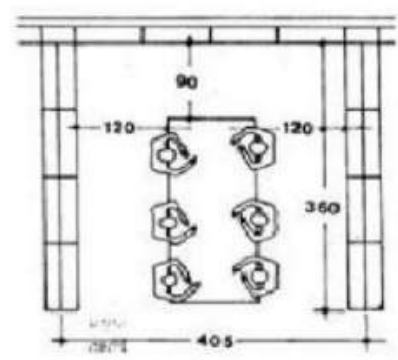

Jarak minimum antara rak buku dan meja baca yaitu $90 \mathrm{~cm}$ tanpa kursi, sedangkan jarak minimum antara rak buku dan meja baca dengan kursi yaitu $120 \mathrm{~cm}$.
Ruang Koleksi Lantai 2

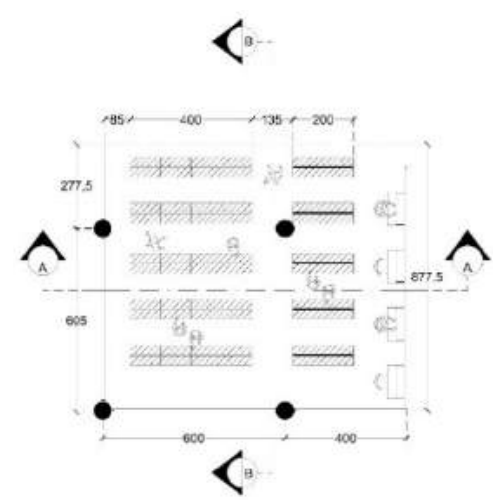

Sedangkan pada zona 3 memiliki jarak $135 \mathrm{~cm}$ sebagai jalan sirkulasi, $85 \mathrm{~cm}$ jarak antar rak koleksi, $110 \mathrm{~cm}$ dimensi antar rak koleksi ke meja baca dengan adanya kursi dan $85 \mathrm{~cm}-100 \mathrm{~cm}$ dimensi antar rak koleksi dengan dinding.

Dimensi antar rak koleksi zona 1-3 mengakibatkan pengguna yang melakukan aktivitas bersama dalam satu waktu menjadi terhambat. Jarak untuk jalur sirkulasi pada area 1 - 3 jarak tersebut tidak memenuhi standar ukuran, yang mengakibatkan pengguna menjadi tidak nyaman Sementara dimensi antar rak koleksi ke meja baca dengan adanya kursi, pada area (1) jarak tersebut sudah mengikuti standar sedangkan pada area (3) jarak masih kurang dari standar.

Tabel diatas menunjukan sirkulasi ruang gerak pada ruang koleksi lantai 2 area baca perpustaakaan Universitas Lampung pada dimensi antar rak koleksi dan jarak untuk jalur sirkulasi pada zona (1) - (3) memiliki jarak yang tidak sesuai dengan standar. Menurut Neufert (2002) ukuran jarak yang dianjurkan yaitu $130 \mathrm{~cm}-230 \mathrm{~cm}$. Sementara sirkulasi untuk dimensi antar rak koleksi ke meja baca dengan kursi, pada zona (1) jarak sudah memenuhi standar dan zona (3) jarak tersebut masih kurang dari standar, menurut Neufert (2002) ukuran jarak yang dianjurkan yaitu $120 \mathrm{~cm}$ untuk dimensi antar rak koleksi ke meja baca dengan adanya kursi.

\subsection{Ruang Koleksi Lantai 3}

Ruang koleksi 3 memiliki luasan area yang paling kecil dari ruang koleksi lantai 1 dan 2, seperti terlihat pada gambar berikut: 


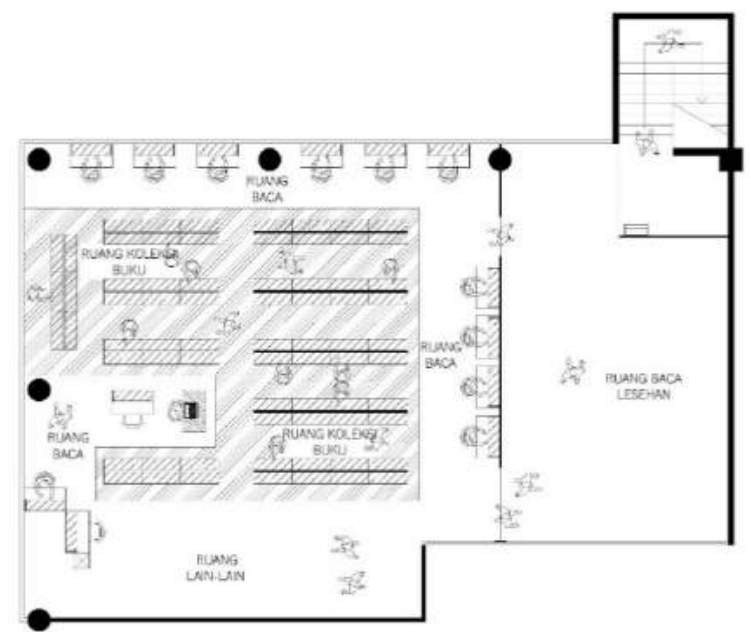

Gambar 18. Zona ruang koleksi lantai 3

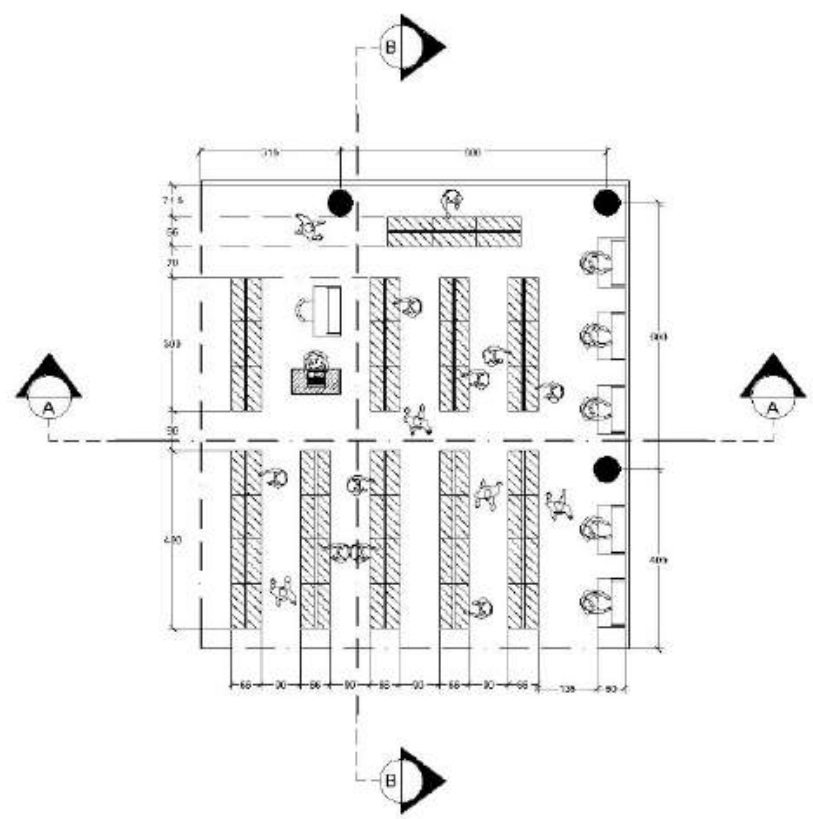

Gambar 19. Denah ruang koleksi lantai 3
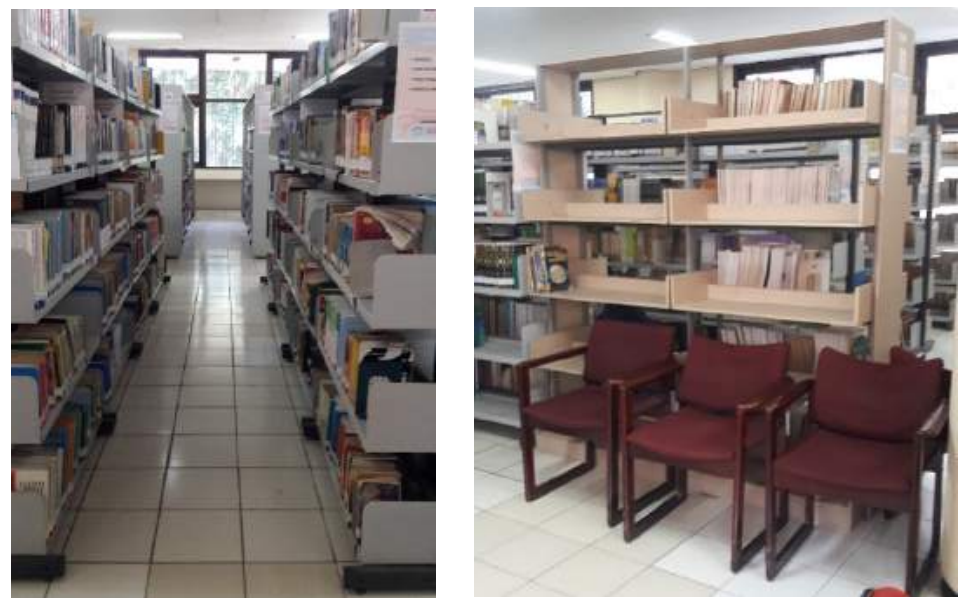

Gambar 20. Suasana ruang koleksi lantai 3 
Ruang koleksi lantai 3 terdapat beberapa perabot seperti rak koleksi dan meja baca, yang memiliki dimensi antar rak koleksi untuk jalan sirkulasi $90 \mathrm{~cm}$, dimensi antar rak koleksi $70 \mathrm{~cm}-90 \mathrm{~cm}$, dimensi antar rak koleksi ke meja baca dengan adanya kursi $135 \mathrm{~cm}$ sedangkan tanpa adanya kursi $68 \mathrm{~cm}$, dan dimensi antar rak koleksi dengan dinding 71,5 $\mathrm{cm}$.

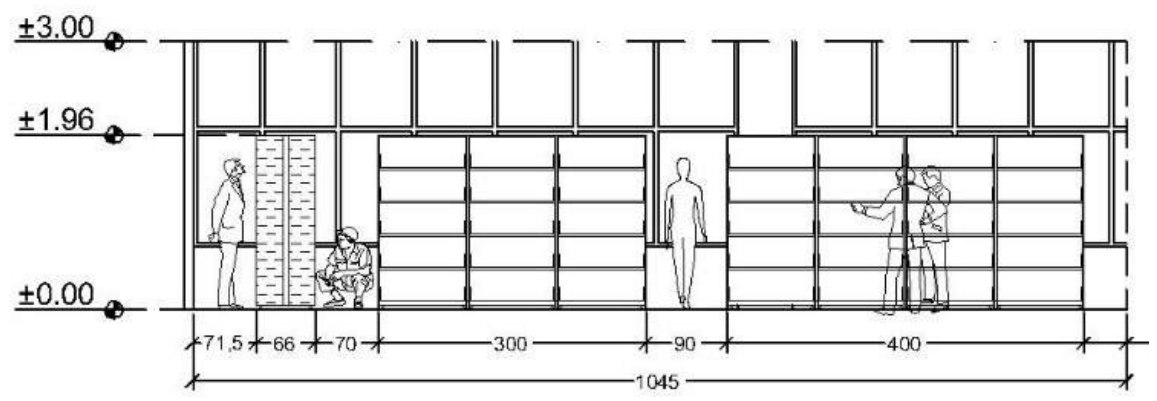

Gambar 21. Potongan A-A ruang koleksi lantai 3

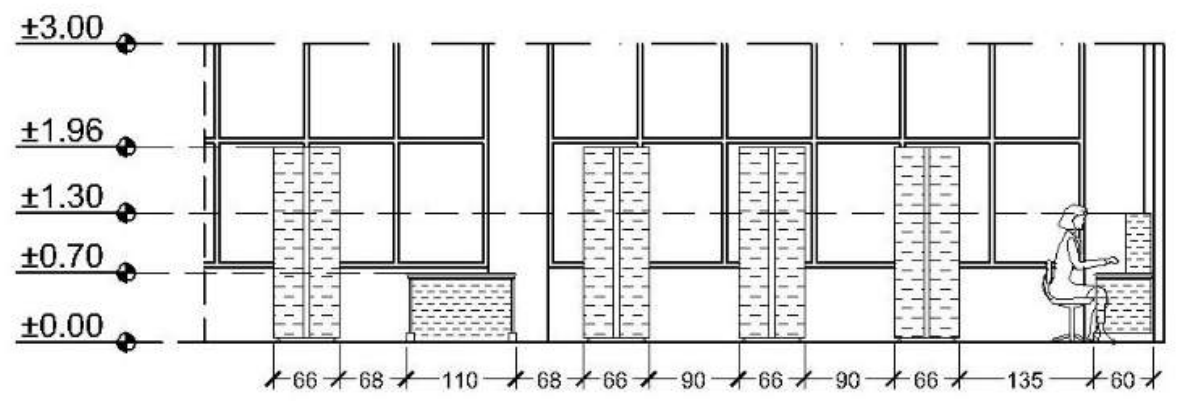

Gambar 22. Potongan B-B ruang koleksi lantai 3

Jarak antar Perabot pada ruang koleksi lantai 3 area baca perpustakaan Universitas Lampung memiliki sirkulasi ruang gerak yang dapat mengakibatkan pengguna tidak nyaman dalam melakukan pergerakan seperti mengambil buku atau berjalan. Berikut perbandingan analisis standar ukuran jarak antar perabot pada ruang koleksi lantai 2.

Tabel 3.Perbandingan ukuran jarak perabot pada ruang koleksi lantai 3 terhadap standar ukuran jarak

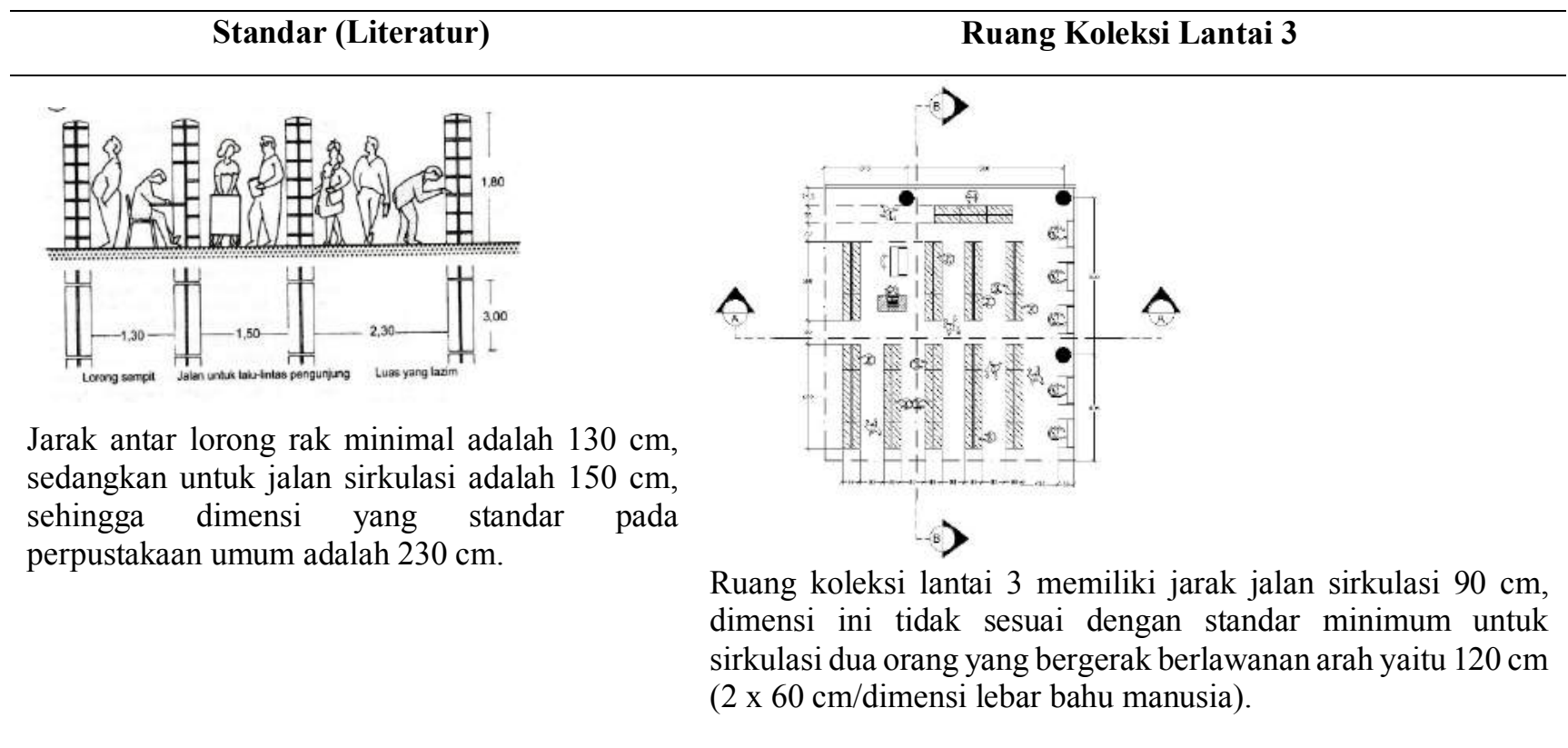




\section{Standar (Literatur)}

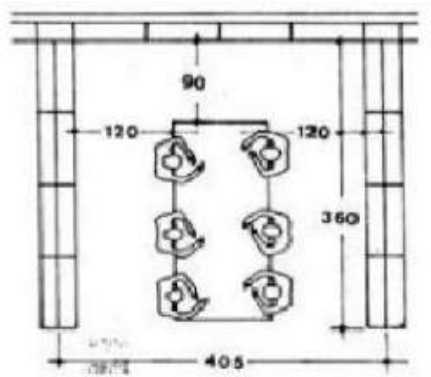

\section{Ruang Koleksi Lantai 3}

Jarak jalan sirkulasi yaitu $70 \mathrm{~cm}-90 \mathrm{~cm}$, jarak sirkulasi tersebut terlalu sempit dan kurang nyaman untuk pengguna dalam melakukan aktivitasnya.

Dimensi antar rak koleksi ke meja baca dengan adanya kursi 135 $\mathrm{cm}$, jarak tersebut sudah memenuhi standar, sedangan dimensi antar rak koleksi ke meja baca tanpa adanya kursi $68 \mathrm{~cm}$, jarak tersebut terlalu sempit dan tidak memberikan sirkulasi ruang gerak yang nyaman bagi pengguna.

Jarak minimum antar rak buku ke meja baca adalah $90 \mathrm{~cm}$ tanpa adanya kursi, sedangkan jarak minimum antar rak buku ke meja baca dengan adanya kursi seperti pada gambar adalah $120 \mathrm{~cm}$.

Dari tabel diatas sirkulasi ruang gerak pada ruang koleksi lantai 3 memiliki dimensi antar rak koleksi yang tidak memenuhi standar untuk ruang gerak pengguna dalam melakukan aktivitas. Menurut Neufert (2002) jarak yang dianjurkan untuk ruang koleksi yaitu $130 \mathrm{~cm}-230 \mathrm{~cm}$. Dan dimensi antara rak koleksi dan mejabaca tanpa adanya kursi juga tidak memenuhi standar yang dianjurkan, sedangkan jarak antara rak koleksi dan meja baca yang memiliki kursi pada area 1 jarak sudah memenuhi standar dan area 3 jarak tersebut sudah memenuhi standar untuk ruang gerak pengguna. Menurut Neufert (2002) jarak yang dianjurkan untuk dimensi antara rak koleksi dan mejabaca tanpa adanya kursi yaitu $90 \mathrm{~cm}$ dan untuk dimensi antar rak koleksi ke meja baca dengan adanya kursi yaitu $120 \mathrm{~cm}$.

\section{Kesimpulan}

Sirkulasi ruang gerak pada ruang koleksi lantai 1 perpustakaan Universitas Lampung memiliki dimensi antar rak koleksi yang tidak sesuai dengan standar. Menurut Neufert (2002) ukuran jarak yang dianjurkan yaitu $130 \mathrm{~cm}-230 \mathrm{~cm}$. Sedangkan dimensi antar rak koleksi ke meja baca tanpa adanya kursi juga tidak memenuhi standar, menurut Neufert (2002) ukuran jarak yang dianjurkan yaitu $90 \mathrm{~cm}$ untuk jarak rak koleksi ke meja baca tanpa adanya kursi.

Sirkulasi ruang gerak pada ruang koleksi lantai 2 area baca perpustaakaan Universitas Lampung pada dimensi antar rak koleksi dan jarak untuk jalur sirkulasi pada zona (1) - (3) memiliki jarak yang tidak sesuai dengan standar, menurut Neufert (2002) ukuran jarak yang dianjurkan yaitu $130 \mathrm{~cm}-230 \mathrm{~cm}$. Sementara sirkulasi untuk dimensi antar rak koleksi ke meja baca dengan kursi, pada zona (1) jarak sudah memenuhi standar dan zona (3) jarak tersebut masih kurang dari standar, menurut Neufert (2002)ukuran jarak yang dianjurkan yaitu $120 \mathrm{~cm}$ untuk dimensi antar rak koleksi ke meja baca dengan adanya kursi.

Sirkulasi ruang gerak pada ruang koleksi lantai 3 memiliki dimensi antar rak koleksi yang tidak memenuhi standar untuk ruang gerak pengguna dalam melakukan aktivitas. Menurut Neufert (2002) jarak yang dianjurkan untuk ruang koleksi yaitu $130 \mathrm{~cm}-230 \mathrm{~cm}$. Dan dimensi antara rak koleksi dan mejabaca tanpa adanya kursi juga tidak memenuhi standar yang dianjurkan, sedangkan jarak antara rak koleksi dan meja baca dengan kursi jarak tersebut dengan kursi, pada area 1 jarak sudah memenuhi standar dan area 3 jarak tersebut sudah memenuhi standar untuk ruang gerak pengguna. Menurut Neufert (2002) jarak yang dianjurkan untuk dimensi antara rak koleksi dan mejabaca tanpa adanya kursi yaitu $90 \mathrm{~cm}$ dan untuk dimensi antar rak koleksi ke meja baca dengan adanya kursi yaitu $120 \mathrm{~cm}$.

Oleh karena itu diperlukan adanya penataan kembali ruang koleksi Perpustakaan Unila. Hal ini bisa dilakukan dengan cara merubah tata ruang pada koleksi dengan mempertimbangkan faktor antropometri agar sirkulasi ruang gerak yang ada didalamnya dapat lebih efektif dan efisien. Komposisi dan luas yang melebihi strandar seperti jarak lalu lintas antar rak buku dengan meja baca dapat dialokasikan untuk luas ruang yang sempit seperti jarak antar rak buku pada ruang koleksi dan jarak antar meja baca pada ruang baca.

\section{Ucapan Terima Kasih}

Penulis mengucapkan terimakasih kepada Kepala Perpustakaan Universitas Lampung (Unila) yang telah mengizinkan penelitian ini. Penulis juga mengucapkan terimakasih kepada Universitas Bandar Lampung yang telah menyediakan sarana dan prasarana selama melakukan penelitian. 


\section{Daftar Pustaka}

Andadari, T. S., Indrosaptono, D., \& Sari, S. R. (2019). Pengaruh Seting Interior Ruang Tunggu terhadap Atribut Kenyamanan Pengguna ( Studi Kasus : Ruang Tunggu BRI ). Jurnal Arsitektur NALARs, 19(1), 69-80.

Fadhlun, M., \& Rahman, N. (2020). Peran Desain Interior Dalam Menunjang Kenyamanan Pengguna di Perpustakaan Badan Pusat Statistik Provinsi Jawa Tengah. ANUVA, 4(1), 81-98.

Handoko, P. (2010). Hubungan tata ruang dalam terhadap kenyamanan fisik pengguna di ruang instalasi gawat darurat rumah sakit islam wonosobo. Universitas Negeri Semarang.

Limantara, O., Kristianto, T. A., Kattu, G. S., Studi, P., Interior, D., Petra, U. K., ... Pendekatan, A. M. (2017). Pengaruh Interior terhadap Perilaku Pengunjung Museum House of Sampoerna Surabaya. Intra, 5(2), 811-819.

Listiani, A. (2007). Pengaruh Ruang Sirkulasi terhadap Kenyamanan Berpindah Kelas pada SMK Negeri 2 Pacitan. Universitas Brawijaya.

Mansyur, M. (2017). Pengaruh Desain Interior terhadap Kenyamanan Membaca Pemustaka di Badan Perpustakaan dan Arsip Daerah (BPAD) Provinsi Sulawesi Selatan. Universitas Islam Negeri Alauddin Makassar.

Neufert, E. (2002). Data Arsitek Jilid 2 (33rd ed.). Jakarta: Erlangga.

Noviani, R., Rusmana, A., Rodiah, S., Studi, P., Perpustakaan, I., \& Padjadjaran, U. (2014). Peranan Desain Interior Perpustakaan dalam Menumbuhkan Minat pada Ruang Perpustakaan. Kajian Informasi \& Perpustakaan, 2(1), 37-46.

Pynkyawati, T., Aripin, S., Iliyasa, E. R. I., \& Ningsih, L. Y. (2014). Kajian Efisiensi Desain Sirkulasi pada Fungsi Bangunan Mall Dan Hotel BTC. Reka Karsa, 2(1), 1-12.

Pynkyawati, T., G, M. A., Hendarsyah, R., \& Amhar, F. (2012). Kajian Desain Sirkulasi Ruang Luar Dan Ruang Dalam Bagi Penyandang Cacat Pada Kawasan Bangunan Ciwalk ( Cihampelas Walk ). Jurnal Arsitektur, 3(1), 7-13.

Safriana, D. D. T. R. M. T. K. P. (2017). Pengaruh Desain Tata Ruang Mesjid terhadap Kenyamanan Pengguna. Seminar Kearifan Lokan Dan Lingkungan Binaan, 355-369. Medan: Departemen Arsitektur Fakultas Teknik USU.

Sainttyauw, A. A. C. Z. J. (2011). Pengaruh Desain Interior Perpustakaan terhadap Kenyamanan Pengguna di Perpustakaan Universitas 17 Agustus 1945 Surabaya. Unair, l(1).

Salsabilla, A., Sadiyarso, E. S., Kridarso, E. R., Arsitektur, J., Teknik, F., \& Trisakti, U. (2019). Studi Komparasi Sirkulasi Ruang Gerak Pengguna pada Area Baca di Perpustakaan Universitas Swasta Bandung. Seminar Intelektual Muda\#2, (September), 125-132. Jakarta: Universitas Trisakti.

Setyosari, P. (2010). Metode Penelitian Pendidikan dan Pengembangan. Jakarta: Kencana.

Sukmadinata, N. S. (2006). Metode Penelitian Pendidikan (2nd ed.). Bandung: PT.Remaja Rosdakarya.

Susanto, D. (2017). Kesinambungan Pola Sirkulasi terhadap Kemudahan Mobilitas Pengunjung. Universitas Katolik Parahyangan.

Suwantoro, S., \& Munawaroh, A. S. (2017). Circulation Pattern of Hospital Type B in Emergency . ( Case Study: Hospital Sumohardjo Urip ). The 4th International Conference on Engineering and Technology Development, (Icetd), 602-620. Bandar Lampung: Universitas Bandar Lampung.

Syafiq, M., Arsitektur, J., Teknik, F., Teknologi, I., Nopember, S., Arief, J., ... Indonesia, S. (2015). Kenyamanan , \& Orientasi Ruang Dalam Sirkulasi Stasiun Kereta Api Gubeng. Sains \& Seni, 1(1), 2-4.

Syah, H. (2010). Pengantar Umum Metodologi Penelitian Pendidikan Pendekatan Verivikatif. Pekanbaru: Suska Pres.

Syoufa, A., \& Hapsari, H. (2014). Pengaruh Pola Sirkualsi Pusat Perbelanjaan Mal terhadap Pola Penyebaran Pengunjung. Desain Konstruksi, 13(2), 46-57.

Widiana, N., \& Munawaroh, A. S. (2020). Circulation Space in the Library Reading Room of University of Lampung. LINEASRS, 3(02), 60-70. 